\title{
The importance of zooplankton in the diets of three native fish species in floodplain waterholes of a dryland river, the Macintyre River, Australia
}

\author{
Elvio S. F. Medeiros · Angela H. Arthington
}

(C) Springer Science+Business Media B.V. 2008

\begin{abstract}
The zooplankton of freshwater systems has been recognized as an important energy resource for fish of small body size that, in turn, provide energy to piscivorous fish consumers higher up the food web. This study evaluates the importance of zooplankton to the diets of three species of fish living in floodplain waterholes of an Australian dryland river. The species selected for study represent different trophic categories in waterhole food webs: Ambassis agassizii is a microcarnivore, Leiopotherapon unicolor is an omnivore, and Nematalosa erebi is a detritivore. Dietary differences among size classes of each species were also evaluated to understand possible ontogenetic shifts in zooplankton consumption. Ambassis agassizii fed primarily on zooplankton $(99.9 \%$, made up mostly of 81.6\% Calanoida and $17.4 \%$ Moinidae), regardless of the size of individual fish. Leiopotherapon unicolor fed on zooplankton $(47 \%$, mostly Daphniidae and
\end{abstract}

Guest editors: U. M. Azeiteiro, I. Jenkinson \& M. J. Pereira Plankton Studies

E. S. F. Medeiros - A. H. Arthington

Australian Rivers Institute and eWater Co-operative

Research Centre, Griffith University, Nathan, QLD 4111,

Australia

E. S. F. Medeiros ( $\square)$

Departamento de Biologia, CCBS, Universidade Estadual da Paraiba, CEP 58109-790, Rua Juvencio Arruda, s/n - Campus Universitário - Bodocongo, Campina Grande, PB, Brazil

e-mail: elviomedeiros@pesquisador.cnpq.br
Moinidae) and aquatic insects (46.7\%). Smaller individuals of Leiopotherapon unicolor (30-49 mm TLtotal length) were responsible for $36.1 \%$ of the plankton consumed by the species. Nematalosa erebi fed on detritus (84.6\%) with zooplankton (Calanoida, Moinidae, and Cyclopoida) contributing only $13.7 \%$ of the mean diet. Smaller individuals (40-69 mm TL) were responsible for $98 \%$ of the plankton consumed by Nematalosa erebi, and individuals of 40-49 $\mathrm{mm}$ (TL) fed exclusively on zooplankton (53.8\% Moinidae and 46.2\% Calanoida). Although the three fish species had different diets, reflecting differences in species-specific and ontogenetic morphological and behavioral characteristics, zooplankton formed the basis of the diet of all species when young. These results confirm the importance of zooplankton as a major food resource for three fish species and smaller size classes of these species in floodplain waterholes of the Macintyre River, Australia.

Keywords Fish - Diet - Zooplankton · Floodplain waterholes · Dryland rivers . Australia

\section{Introduction}

The trophic ecology of fish in floodplain river systems is of particular interest given that rivers around the globe are losing their connections to the surrounding floodplain and hence may experience 
reduced benefits from floodplain energy subsidies (Welcomme et al., 2006). In undisturbed floodplain rivers, fish that feed and grow on the floodplain may provide food for higher order consumers living temporarily on the inundated floodplain (e.g., Kingsford et al., 1999; Balcombe et al., 2005), or their energy reserves may subsidize fish consumers in the main channel after floods recede (Winemiller, 1996). In many systems, however, isolated waterbodies left on the floodplain (lakes, lagoons, and waterholes) also support fish throughout seasonal or extended dry periods (Rodriguez \& Lewis, 1997; Arthington et al., 2005). It is of interest to know how such fish sustain themselves during dry periods as these remnant populations can provide important sources of individuals for recolonization of the river network when flooding is resumed (Welcomme, 1985; Morton et al., 1995; Saint-Paul et al., 2000). Fish consumers in floodplain rivers can use a range of trophic resources for nutrition (Balcombe et al., 2005). These resources usually have two distinct origins: they may be autochthonous, derived from within-waterhole primary production, or allochthonous, derived from terrestrial inputs (Bunn et al., 2003). For species that do not feed directly on primary production (phytoplankton, aquatic plants, riparian leaves, and flowers), zooplankton may be an important energy resource for small species and the smaller size classes of large species that, in turn, provide energy to piscivorous fish and other consumers higher up the food web (Kingsford et al., 1999). Within this context, zooplankton have been recognized as an important trophic link between primary production (either autochthonous or allochthonous) and consumers (e.g., Winemiller, 1996; Jones et al., 1999).

This study evaluates the importance of zooplankton to the diets of three species of fish in floodplain waterholes of an Australian dryland floodplain river (the Macintyre River on the border between Queensland and New South Wales). It also seeks to understand the contribution of zooplankton and other important food items to different size classes of fish, since it is a common observation that fish dietary composition and diversity change with ontogeny (Werner \& Gilliam, 1984; Winemiller, 1989; Pusey et al., 1995, 2000). Three species were selected for study to represent different components of the trophic web. The first species (Ambassis agassizii Steindachner 1867) is a microphagic carnivore that consumes aquatic insects, micro-, and macro-crustaceans (Pusey et al., 2004). This species may also consume small amounts of aquatic and terrestrial vegetation, molluscs, fish, and terrestrial invertebrates. According to Pusey et al. (2004) Ambassis agassizii is a small species (70-80 mm TL) with a large and oblique mouth. It is relatively widespread, occurring in coastal and inland drainages of eastern Australia. The second species, Leiopotherapon unicolor (Günther 1859), is an omnivore with a relatively diverse diet comprised of aquatic invertebrates, such as chironomids, simulid, and trichopteran larvae, and ephemeropteran nymphs, as well as micro- and macro-crustaceans (Pusey et al., 2004). Leiopotherapon unicolor is a moderately-sized and robust species, commonly reaching $150 \mathrm{~mm}$ (SL-standard length) and occasionally larger. The mouth has a slight oblique, large gape (Pusey et al., 2004). This is one of the most widely distributed Australian freshwater fishes, second only to the bony bream (Nematalosa erebi Günther 1868), the third study species. The bony bream is primarily detritivore/ algivore (Pusey et al., 2004) with the algal contribution being dominated by microbenthic taxa. Even though detritus comprises a large portion of the diet of Nematalosa erebi, it may be overestimated due to methodological constraints associated with difficulties in separate detritus from microalgae. This is a moderate-size fish with most individuals reaching 150-300 mm SL (Pusey et al., 2004). Nematalosa erebi has a two-part stomach (Atkins, 1984; Gerking, 1994) comprising a muscular and distensible cardiac portion, also known as the pharynx or foregut, and a gizzard-like pyloric portion which is also muscular but rigid. In this species, both foregut and gizzard were considered in the estimation of stomach fullness and diet composition.

\section{Materials and methods}

This study was conducted on the floodplain of the Macintyre River, a dryland river in the Border Rivers catchment of eastern Australia. This catchment is located along the border between southern Queensland and northern New South Wales and comprises a major portion of the headwaters of the Barwon and Darling River systems (Fig. 1). In the study area, a number of streams diverge from the Macintyre River 
Fig. 1 Location of the study sites on the floodplain of the Macintyre River and the Border Rivers catchment within the Murray-Darling River system

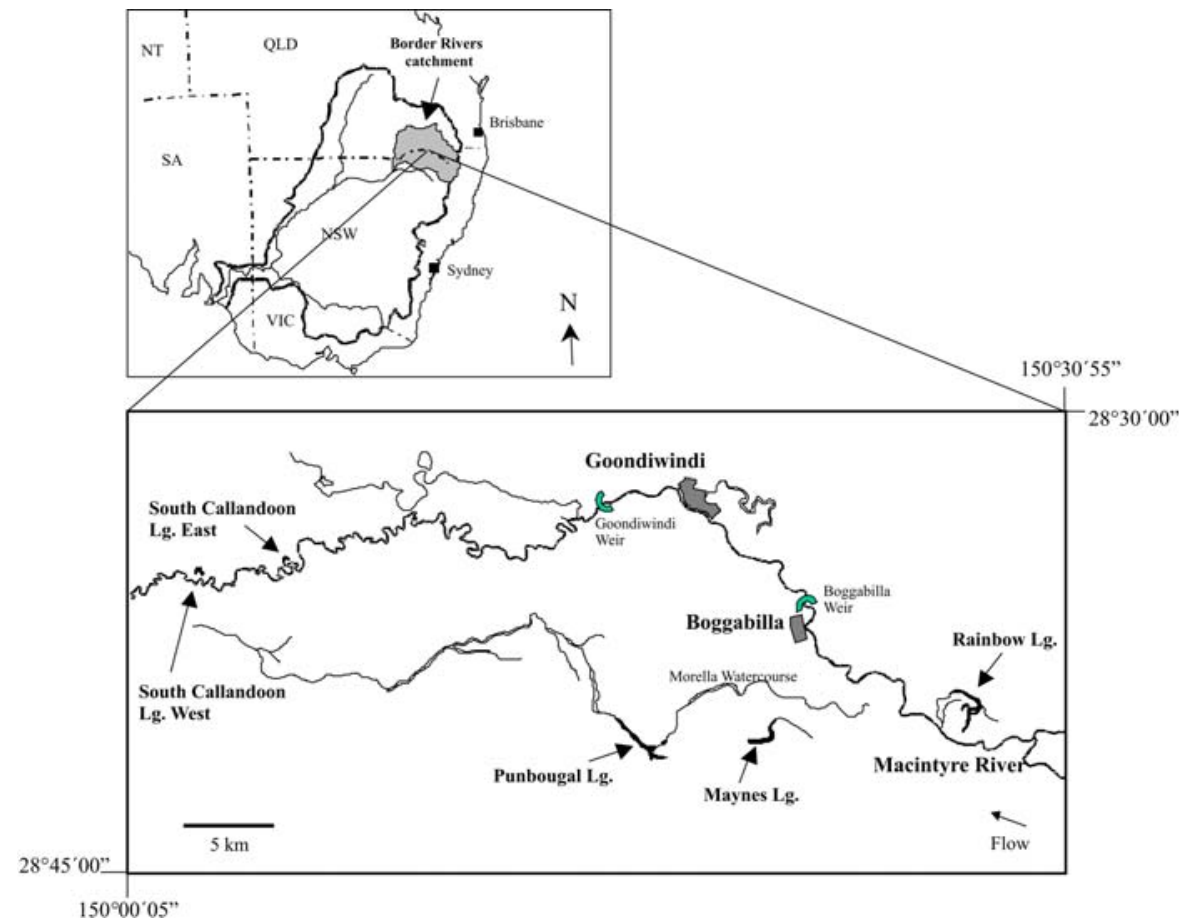

in the vicinity of the towns of Boggabilla and Goondiwindi, where the river passes through a relatively well-defined floodplain containing numerous intermittent and semi-permanent billabongs (oxbow lakes) on prior river channels. The study period spanned 2 years (2002 and 2003) and was characterized by relatively low flows in the main channel of the Macintyre River, with only minor to moderate floods occurring in the early months of each year (late summer). Only two of the waterholes studied were flooded (South Callandoon East and Rainbow Lagoon) and one dried up completely (South Callandoon West) during this study. The remaining lagoons decreased in surface area and volume continuously throughout the study period but did not dry up completely.

The habitat characteristics of waterholes, such as the amount of debris in the water, shading from riparian vegetation, and macrophyte growth, varied spatially (between waterholes) over the 2-year study period. Most temporal variation in habitat characteristics occurred between flooded and non-flooded sites, as the latter presented significantly lower proportions of habitat elements, such as aquatic and overhanging vegetation, algae, debris, leaf litter, and root masses. In flooded lagoons many of these habitat elements increased in proportional area after wet season flooding. Water quality parameters also varied among lagoons and throughout the study period. Again, most variation occurred between flooded and non-flooded waterholes, with the flooded waterholes showing clear changes in water quality parameters in relation to flooding, when $\mathrm{pH}$, conductivity, dissolved oxygen, and turbidity were lower and water temperatures were higher than during dry periods. Further details can be found in Medeiros (2005).

Fish were collected from a variety of sites on the floodplain of the Macintyre River and sampling was conducted at different time periods during 2002 and 2003, using a collection method that aimed to collect a wide range of fish body sizes (Table 1). Each site was sampled using a seine net $(25 \mathrm{~m}$ length $\times 2 \mathrm{~m}$ height $\times 1 \mathrm{~cm} \mathrm{mesh}$ ) for approximately $2 \mathrm{~h}$ between 11:00 a.m. and 2:00 p.m. (in accordance with Medeiros \& Arthington, 2008). Individuals of the target species were preserved in $4 \%$ buffered formalin immediately after capture. Later in the laboratory fish were transferred to $70 \%$ ethanol and the necessary measurements were performed to determine size classes. The size classes chosen for ontogenetic diet comparisons were based on the range of sizes available in collections from the study sites and the 


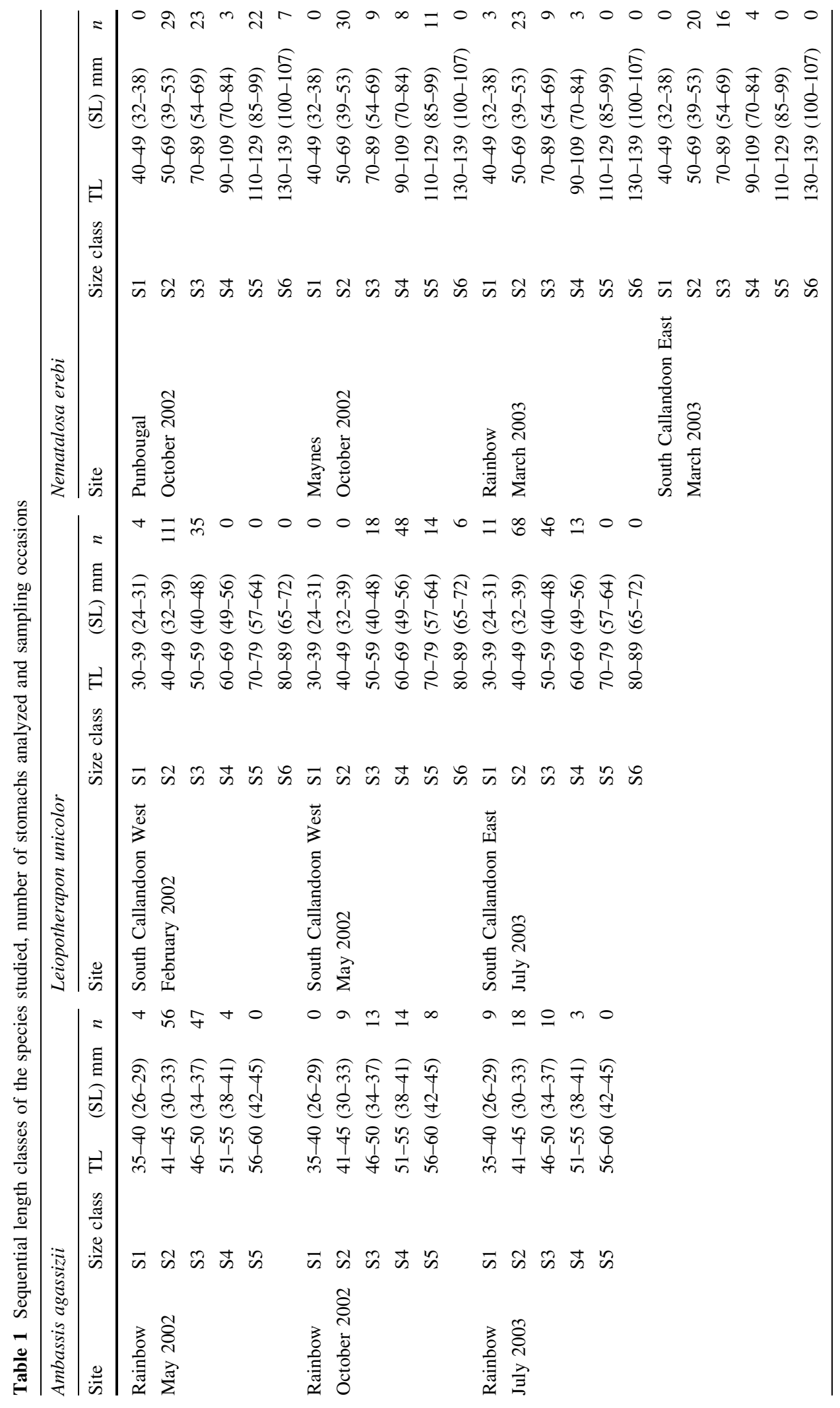


overall number of individuals caught. In the laboratory, each individual fish was measured (SL and TL) to the nearest millimeter with Vernier calipers. For the dietary analysis, the stomach of each fish was removed, blotted, and then placed in a petri dish, where the degree of stomach fullness was estimated through eye by assigning a score between 0 (empty) and 10 (fully distended with food), reflecting percentages of stomach volume occupied by food. The proportional contribution of each class of food items to the diet of individual fish was estimated using Hyslop's (1980) indirect volumetric method, where stomach items within each prey (or other food) category are lumped together and squashed to a uniform depth of $1 \mathrm{~mm}$ and the area covered taken to represent the volumetric contribution of that food category to the total stomach contents in $\mathrm{mm}^{3}$ (cf. Arthington, 1992; Pusey et al., 2000). Prey items were identified to the lowest possible level of taxonomic resolution but not to species. The contribution of each dietary item to the diet of a fish species was expressed as the mean of the percentage volumetric contribution made by each dietary item to the stomach contents of each individual of that species.

The proportional volumetric dietary data for individual representatives of each species from each sampling occasion were allocated into size classes based on the range of sizes available (TL) and the number of individuals of each size class (Table 1); mean diet composition was calculated for each of these size groups (Schafer et al., 2002). Unidentified material was excluded from this analysis as the inclusion of values for unidentified material could bias the results. For all statistical analysis, only stomachs with fullness equal to or greater than $20 \%$ were considered in order to prevent bias in the calculation of the proportional contribution of each food category (Pusey et al., 1995).

Overall similarities in dietary composition of each size class of each species within and between sampling occasions were analyzed using the ordination technique non-metric multidimensional scaling (NMS) (McCune \& Mefford, 1999). Data were arcsine square root transformed, as is appropriate for proportional multivariate data (McCune \& Grace, 2002). The Relative Sorensen (Kulcynski) distance measure was used to construct the similarity analysis and all graphical outputs were Varimax-rotated. The multi-response permutation procedure (MRPP) (Biondini et al., 1985; McCune \& Mefford, 1999) was used to test for differences among groups (size classes or sampling occasions). One-way ANOVA of arcsine transformed data was used to investigate the variation in proportional contribution of specific dietary items between size classes.

\section{Results}

The overall diet composition of the three study species comprised five major food categories: zooplankton $(53.6 \%)$, detritus $(29.1 \%)$, aquatic insects $(15.6 \%)$, and vegetable matter $(0.7 \%)$ with other food items comprising $1 \%$ of the overall diet (Table 2). The relative contribution of dietary items varied greatly among species. Zooplankton made up to 99.9\% of the mean diet of Ambassis agassizii which was comprised mostly of Calanoida (81.6\%) and Moinidae (17.4\%). Leiopotherapon unicolor fed on zooplankton (47\% of the mean diet, mostly Daphniidae and Moinidae), and aquatic insects (46.7\%). Nematalosa erebi fed mostly on detritus (84.6\% of the mean diet), however, zooplankton made a substantial contribution (13.7\%, especially Calanoida, Moinidae, and Cyclopoida) (Table 2).

The relative contribution of dietary items also varied among sampling occasions, waterhole locations, and fish developmental stage. A strong temporal gradient was observed in the diet composition of Ambassis agassizii. The ordination plot shows clear segregation in diet composition between the three sampling occasions (Fig. 2) (MRPP: $\mathrm{A}=0.48, P<0.05)$. An ontogenetic shift in the proportion of zooplankton item consumed by $A m b$ assis agassizii is observable for both 2002 sampling occasions, as points for dietary samples tended to progress from left to right in the ordination plot. In general for this species, size classes S1 $(35-40 \mathrm{~mm}$ $\mathrm{TL})$ and S2 (41-45 $\mathrm{mm}$ TL) tended to show higher differentiation compared to the other size classes. However, this was not the case for the 2003 sampling occasion when Ambassis agassizii fed almost exclusively on calanoids (Fig. 3). Even though the main dietary items remain similar for all sampling occasions, their proportional contribution changed across seasons and size classes (Fig. 3). On all sampling occasions, calanoid copepods were the main food 
Table 2 Contribution by volume (\% Vol) and frequency of occurrence (\% Freq) of different taxa and major dietary categories to the overall diets of Ambassis agassizii, Leiopotherapon unicolor and Nematalosa erebi

\begin{tabular}{|c|c|c|c|c|c|c|}
\hline \multirow[t]{2}{*}{ Major categories and dietary items } & \multicolumn{2}{|c|}{ A. agassizii } & \multicolumn{2}{|c|}{ L. unicolor } & \multicolumn{2}{|l|}{ N. erebi } \\
\hline & $\% \mathrm{Vol}$ & $\%$ Freq & $\% \mathrm{Vol}$ & $\%$ Freq & $\%$ Vol & $\%$ Freq \\
\hline \multicolumn{7}{|l|}{ Zooplankton } \\
\hline Calanoida & 81.6 & 95.4 & 9.1 & 37.7 & 7.8 & 34.1 \\
\hline Cyclopoida & & & 0.8 & 21.7 & 0.2 & 4.5 \\
\hline Moinidae & 17.4 & 53.8 & 11.6 & 38.2 & 5.7 & 36.8 \\
\hline Daphniidae & 0.97 & 10.2 & 24.2 & 38.2 & & \\
\hline Bosminidae & & & 0.1 & 0.3 & & \\
\hline Chydoridae & 0.01 & 1.0 & 1.2 & 13.9 & & \\
\hline \multicolumn{7}{|l|}{ Aquatic insects } \\
\hline Leptophlebiidae & & & 1.0 & 4.5 & & \\
\hline Coenagrionidae & & & 8.9 & 7.0 & & \\
\hline Notonectidae & & & 1.7 & 0.8 & & \\
\hline Corixidae & & & 4.6 & 19.8 & & \\
\hline Chironomidae (Larvae) & & & 19.0 & 62.3 & 0.01 & 0.5 \\
\hline Chironomidae (Pupae) & 0.01 & 0.5 & 9.4 & 28.6 & & \\
\hline Ecnomidae & & & 1.9 & 7.5 & & \\
\hline Leptoceridae & & & 0.2 & 0.8 & & \\
\hline Hydroptilidae & & & 0.04 & 0.5 & & \\
\hline \multicolumn{7}{|l|}{ Vegetable matter } \\
\hline Volvox colony & & & & & 0.8 & 18.6 \\
\hline Filamentous algae & & & & & 0.01 & 3.6 \\
\hline Algae matter & & & & & 0.02 & 2.3 \\
\hline Plant matter & & & 0.6 & 14.7 & 0.8 & 56.4 \\
\hline Detritus & 0.01 & 0.5 & 2.7 & 18.2 & 84.6 & 86.4 \\
\hline \multicolumn{7}{|l|}{ Other } \\
\hline Ostracoda & & & 2.2 & 21.1 & 0.05 & 12.7 \\
\hline Conchostraca & & & 0.7 & 8.6 & & \\
\hline Nematoda & & & 0.02 & 0.5 & 0.01 & 0.5 \\
\hline Planorbidae & & & 0.04 & 0.5 & & \\
\hline Stomachs analyzed & 195 & & 374 & & 220 & \\
\hline
\end{tabular}

item consumed by all size classes of Ambassis agassizii with a minimum contribution of $41 \%$ (S2, October 2002), followed by moinid cladocerans with contributions of up to $59 \%$ of the ingested items for any given size class. In July 2003, contributions of dietary items other than calanoids were insignificant, which led to the lack of clear segregation in ordination space among size classes on this sampling occasion (Fig. 3). Apart from that, the proportional contribution of Moinidae tended to decrease from smaller to larger individuals, even though the differences in mean proportion of Moinidae and Calanoida between size classes were significant only in October
2002 (one-way ANOVA, $F=5.86 ; \quad$ df $=3,40$; $P=0.0020$ and $F=5.4 ;$ df $=3,40 ; P=0.0032$, respectively). Nevertheless, calanoids became increasingly more important to the diet of Ambassis agassizii as individuals of this species grew.

The dietary composition of Leiopotherapon unicolor showed significant spatio-temporal variation, as shown in the NMS ordination plot (Fig. 4). Samples from South Callandoon Lagoon East are arrayed to the bottom of the ordination space, whereas samples from South Callandoon Lagoon West are spread in the middle and top areas of the plot (MRPP: $\mathrm{A}=0.47, \quad P<0.05)$. There were also temporal 


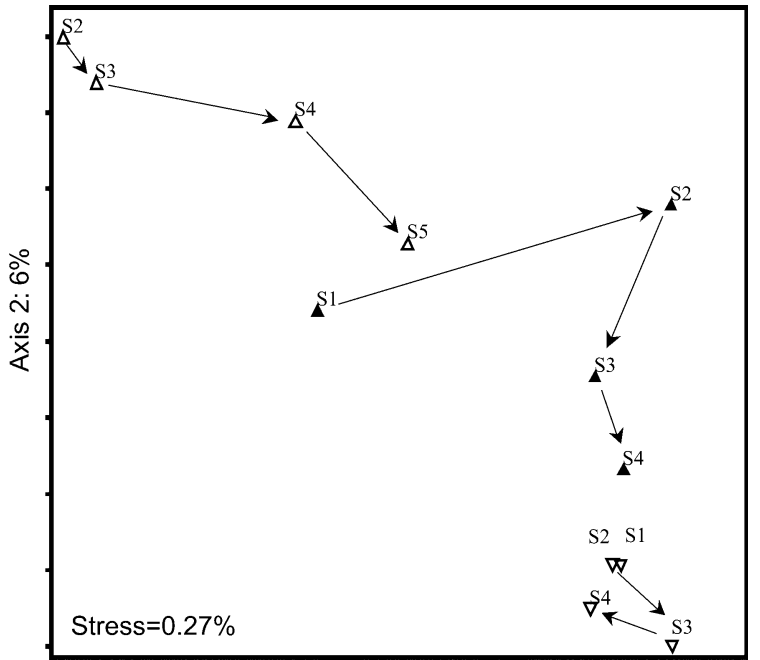

Axis $1: 93 \%$

Fig. 2 Two-dimensional solution for NMS based on mean proportional volume of dietary items for sequential size classes of Ambassis agassizii from Rainbow Lagoon. Percentages shown on axes represent the amount of variance explained by that axis. Size classes are indicated as $\mathrm{S} 1=35-40 \mathrm{~mm}$, $\mathrm{S} 2=41-45 \mathrm{~mm}, \mathrm{~S} 3=46-50 \mathrm{~mm}, \mathrm{~S} 4=51-55 \mathrm{~mm}$, and S5 $=56-60 . \quad \Delta=$ October 2002, $\boldsymbol{\Delta}=$ May 2002, and $\nabla=$ July 2003

differences between South Callandoon West dietary samples collected in February and May 2002 (MRPP: $\mathrm{A}=0.33, P<0.05)$. The ordination plot also shows a clear shift in diet composition of increasing size classes of Leiopotherapon unicolor on all three sampling occasions, with a progression of dietary samples of sequential size classes arrayed from left to right for each sampling occasion. Smaller individuals (size S1, 30-39 mm TL) were clearly segregated from the more intermingled larger size classes during February 2002 and July 2003, whereas in May 2002 all size classes were considerably segregated from each other (Fig. 4).

In February 2002 and July 2003, the smallest size class S1 (30-39 mm TL) of Leiopotherapon unicolor had a markedly different dietary composition compared to the remaining size classes. In general, in July 2003 at South Callandoon Lagoon East, smaller (S1) individuals of Leiopotherapon unicolor showed higher consumption of chironomid pupae (13.5\%) and the contribution of these insects to the diet tended to decrease with body size (Fig. 5). In contrast, other aquatic insects, such as Ecnomidae (Trichoptera) and Coenagrionidae (Odonata), which were not consumed

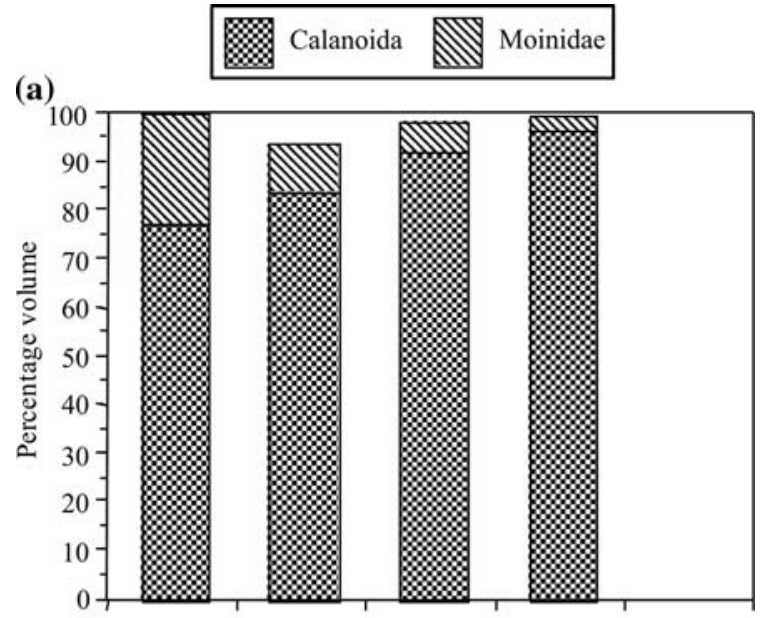

(b)

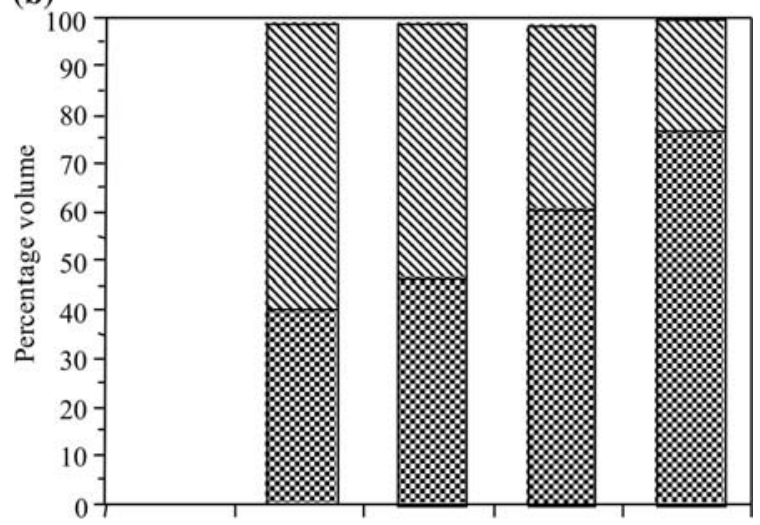

(c)

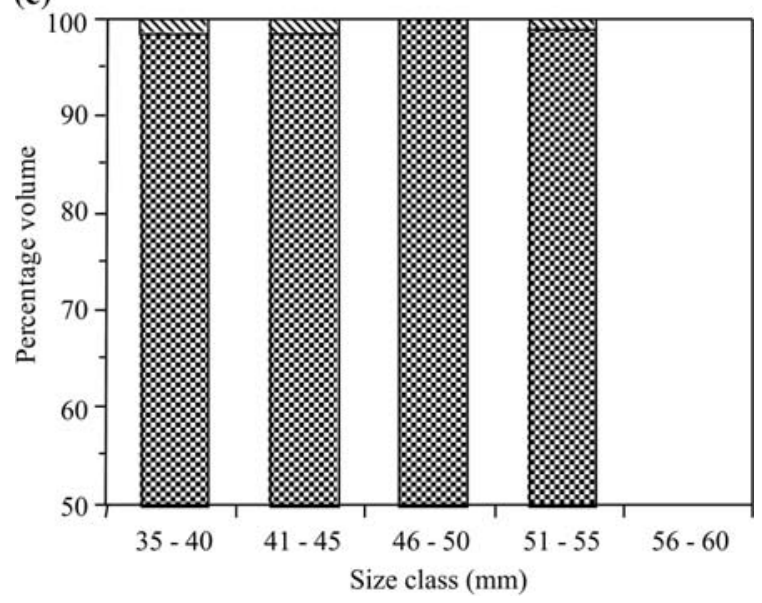

Fig. 3 Percentage contributions by volume of dietary items to the diets of sequential size classes of Ambassis agassizii collected during different seasons in Rainbow Lagoon. (a) May 2002, (b) October 2002 and (c) July 2003. Only important items are shown. Note that the percentage volume axis in $\mathbf{c}$ is on a different scale to enhance observation of less abundant items 


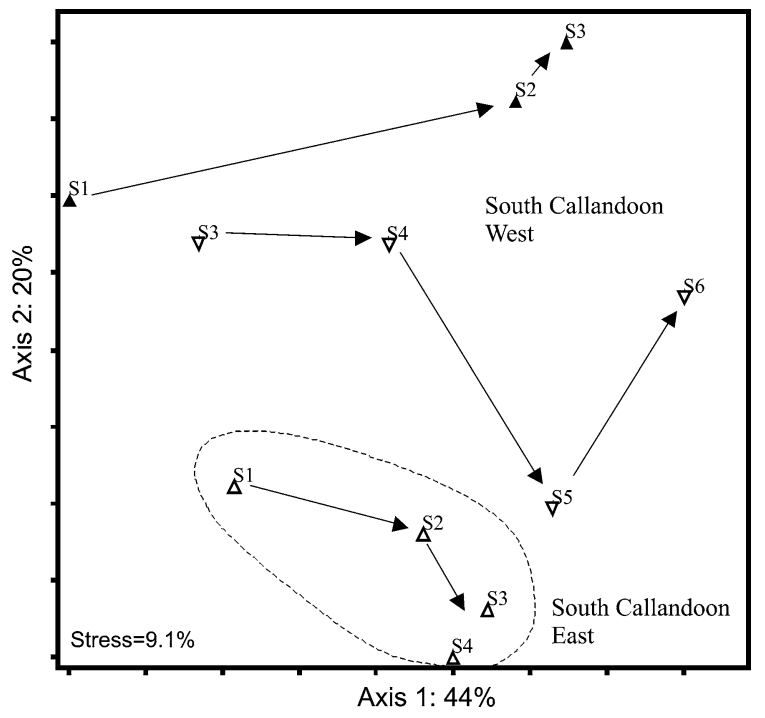

Fig. 4 Two-dimensional solution for NMS based on mean proportional volume of dietary items for sequential size classes of Leiopotherapon unicolor. Percentages shown on axes represent the amount of variance explained by that axis. Size classes are indicated as $\mathrm{S} 1=30-39 \mathrm{~mm}, \mathrm{~S} 2=40-49 \mathrm{~mm}$, $\mathrm{S} 3=50-59 \mathrm{~mm}, \quad \mathrm{~S} 4=60-69 \mathrm{~mm}, \mathrm{~S} 5=70-79 \mathrm{~mm}$, and S6 = 80-89. $\boldsymbol{\Delta}=$ February 2002 (South Callandoon West), $\nabla=$ May 2002 (South Callandoon West), and $\Delta=$ July 2003 (South Callandoon East)

by $\mathrm{S} 1$ individuals, became increasingly important in the diet of Leiopotherapon unicolor as fish size increased. Consumption of Ecnomidae increased from 0 for size class $\mathrm{S} 1$ to $8.4 \%$ for larger fish in size class S4 (60-69 mm TL), whereas consumption of Coenagrionidae increased from $2.7 \%$ for $\mathrm{S} 1$ to $22.6 \%$ for S4. Zooplankton, mostly Calanoida (8.1$23.8 \%$ ) and Daphniidae (14.9-31.4\%), were similarly consumed by all size classes of Leiopotherapon unicolor from South Callandoon Lagoon East. Larval stages of chironomids (19.2-30.8\%) were also important at this site. Similarly, contributions of calanoids $(37.9 \%)$ and chironomid larvae $(42.5 \%)$ and pupae $(11.5 \%)$ to the diet of small (S1) Leiopotherapon unicolor were also higher in samples from South Callandoon Lagoon West (February 2002) (Fig. 5), although these items were progressively less important for larger individuals (S2, 40-49 and S3, 50-59 mm TL). In contrast, larger individuals showed an increase in consumption of microcrustaceans, such as Moinidae (from $1.1 \%$ at $\mathrm{S} 1$ to $46.3 \%$ at $\mathrm{S} 3$ ) and Ostracoda (from 0 at $\mathrm{S} 1$ to $15.5 \%$ at S3). Consumption of corixid hemipterans also increased from 0 for size class $\mathrm{S} 1$ to $6.9 \%$ for $\mathrm{S} 3$. The

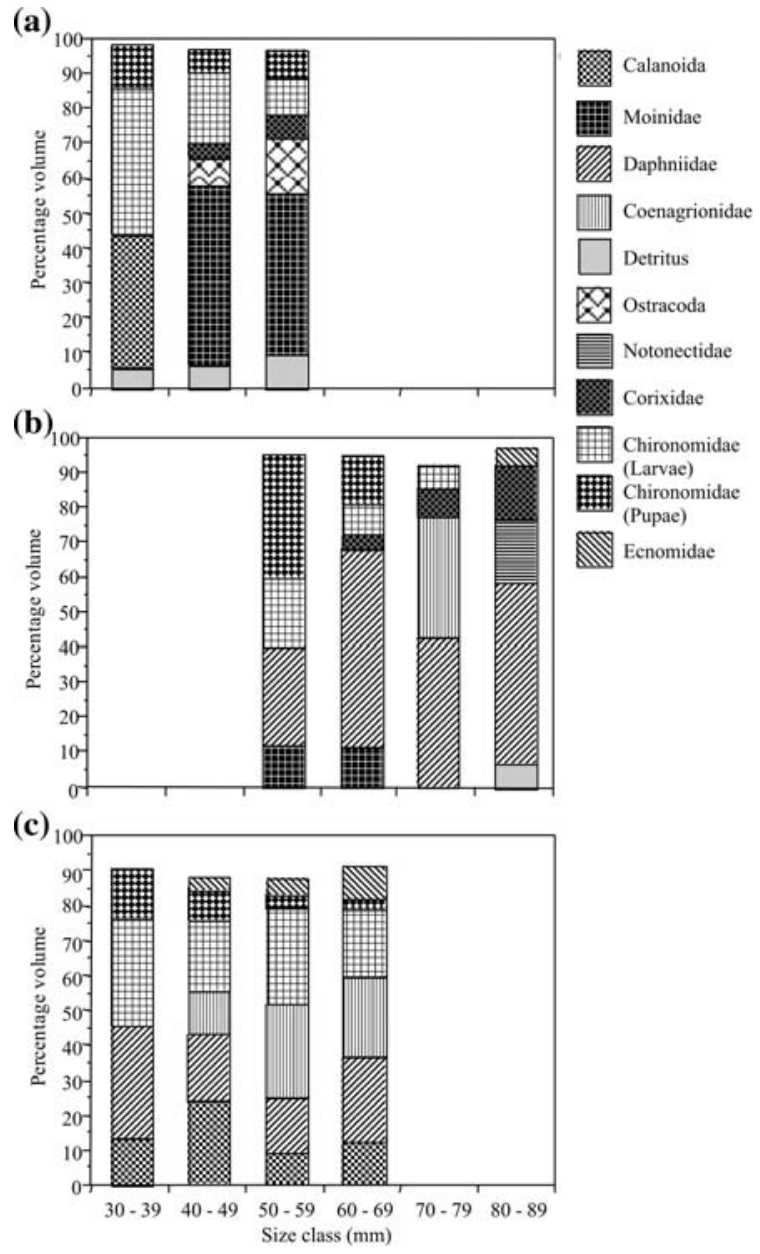

Fig. 5 Percentage contributions by volume of dietary items to the diets of sequential size classes of Leiopotherapon unicolor. South Callandoon West February 2002 (a) and May 2002 (b) and South Callandoon East July 2003 (c). Only important items are shown

contribution of detrital matter to the diets of Leiopotherapon unicolor was similar across size classes, ranging from 5.7\% to 9.5\%. In May 2002 (South Callandoon Lagoon West) size classes S1 and S2 were not present (Fig. 5). Even so, a decrease in consumption of chironomids (larvae and pupae) and Moinidae was observed for the remaining size classes. Chironomid larvae progressively decreased from $19.8 \%$ of diet composition for S3 to only $2.9 \%$ for S6 (80-89 mm TL), chironomid pupae decreased from $34.6 \%$ for S3 to $0.4 \%$ for S6 and consumption of Moinidae progressively decreased from $12.1 \%$ at S3 to $1.2 \%$ for the largest size class S6. Interestingly, during May 2002, larger size classes (S4 to S6) 


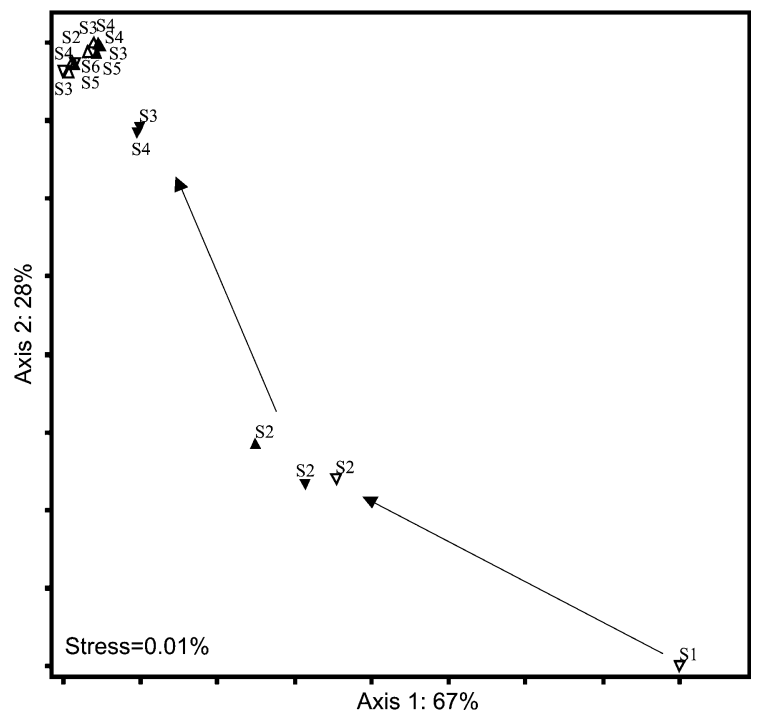

Fig. 6 Two-dimensional solution for NMS based on mean proportional volume of dietary items for sequential size classes of Nematalosa erebi. Percentages shown on axes represent the amount of variance explained by that axis. Size classes are indicated as $\mathrm{S} 1=40-49 \mathrm{~mm}, \mathrm{~S} 2=50-69 \mathrm{~mm}, \mathrm{~S} 3=70$ $89 \mathrm{~mm}, \quad \mathrm{~S} 4=90-109 \mathrm{~mm}, \quad \mathrm{~S} 5=110-129 \mathrm{~mm}$, and $\mathrm{S} 6=$ 130-139 mm. $\Delta=$ October 2002 (Punbougal Lg.), $\boldsymbol{\Delta}=$ October 2002 (Maynes Lg.), $\nabla=$ March 2003 (Rainbow Lg.), and $\boldsymbol{\nabla}=$ March 2003 (South Callandoon East)

showed an increase in consumption of aquatic invertebrates (except for chironomids), with high consumption of Coenagrionidae (34\% for S5, 70$79 \mathrm{~mm} \mathrm{TL}$ ), Hemiptera (18.2\% of Notonectidae for S6 and up to $14.8 \%$ of Corixidae for S6), and Ecnomidae with up to $4.2 \%$ for S6.

Overall, zooplankton provided an important food category for Leiopotherapon unicolor. Consumption of Calanoida reached up to $37.9 \%$ (S1, South Callandoon Lagoon West, February 2002) and the contribution of Daphniidae to the diet of this species reached up to 56\% (S4, South Callandoon Lagoon West, May 2002). Furthermore, zooplankton was equally important for smaller and medium size classes of Leiopotherapon unicolor. The proportion of zooplankton consumed by smaller to larger sizeclasses of this species was $\mathrm{S} 1=16.7 \%, \mathrm{~S} 2=19.4 \%$, $\mathrm{S} 3=23.1 \%, \mathrm{~S} 4=21.1 \%, \mathrm{~S} 5=9.5 \%$, and $\mathrm{S} 6=$ $10.3 \%$ of the total amount of zooplankton consumed by all size classes.

Strong dietary changes with ontogeny were evident for Nematalosa erebi and were reflected in the ordination plot by a clear trajectory of change in diet with increasing size of fish (Fig. 6). The NMS plot shows a gradient from bottom-right to top-left of ordination space, with size classes of larger individuals being arrayed to the left side of the plot. Furthermore, a clear segregation between smaller individuals of size classes S1 (40-49 mm TL) and S2 (50-69 $\mathrm{mm}$ TL) as well as between these size classes and the remaining ones is apparent in Fig. 6. Also significant was the spatial variation in dietary composition (MRPP: $\mathrm{A}=0.17, \quad P<0.05$ ), despite considerable similarity in food items consumed across sites (Fig. 6). Nematalosa erebi fed mostly on detritus (84.6\%) and only $13.7 \%$ on zooplankton (Calanoida, Moinidae, and Cyclopoida) (Table 2). Detrital material contributed at least $52.9 \%$ of the diet of this species when all size classes are considered together. However, smaller individuals (S1 and S2) showed consistently higher consumption of zooplankton (mostly Moinidae and Calanoida) than larger individuals (>69 mm TL, S3-S6) (Fig. 7). Smaller individuals (40-69 mm TL) were responsible for $98 \%$ of the plankton consumed by Nematalosa erebi, $45.6 \%$ being for size class $\mathrm{S} 1$ and $52.4 \%$ for S2. All individuals sampled from 40 to $49 \mathrm{~mm}$ TL (Rainbow Lagoon) presented a diet consisting exclusively of zooplankton (Moinidae 53.8\% and Calanoida 46.2\%). In Punbougal Lagoon, the diet of all size classes consisted mostly of detritus and to a much smaller extent, vegetable matter.

\section{Discussion}

This study has demonstrated the overall importance of zooplankton as a food resource for fish belonging to three contrasting trophic categories inhabiting isolated waterholes of an Australian dryland floodplain river. The contribution of zooplankton varied from $99.9 \%$ in the micro-carnivore Ambassis agassizii to $47 \%$ in the omnivore Leiopotherapon unicolor and $13.7 \%$ in the detritivore Nematalosa erebi. Moreover, zooplankton formed the basis of the diet of all species when young and relatively small, with all three species showing distinct shifts in diet composition across size classes. These trends varied across seasons and/or among waterhole locations. Since each waterhole presented a different pattern of flooding and subsequent drying, some being flooded and others not (Medeiros, 2005), such seasonal and spatial variability is likely to have an impact on the 

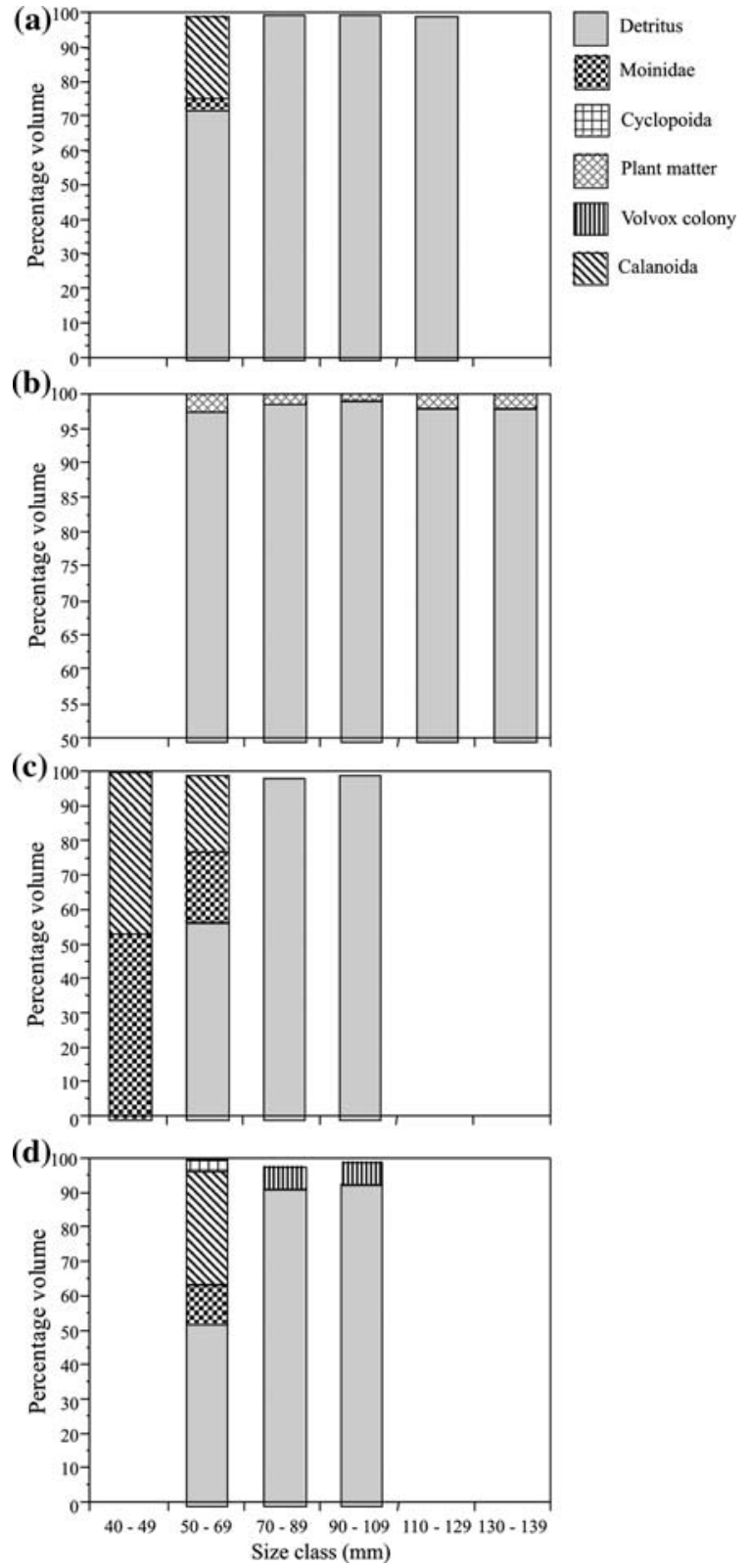

Fig. 7 Percentage contributions by volume of dietary items to the diets of sequential size classes of Nematalosa erebi. October 2002 (a) Maynes Lg. and (b) Punbougal Lg. March 2003 (c) Rainbow Lg. and (d) South Callandoon East. Only important items are shown. Note that the percentage volume axis in $\mathbf{b}$ is on a different scale to enhance observation of less abundant items

availability of various food items. This variation in food resources could explain much of the observed variation in ontogenetic dietary shifts across the range of lagoons studied, however, exploration of patterns of resource availability was beyond the scope of this study.

In floodplain waterholes of the Macintyre River, Ambassis agassizii tended to feed more on calanoids and, to a lesser extent on daphniid cladocerans, as it grew, whereas smaller individuals tended to consume more moinid cladocerans than larger ones. There is no information from the literature indicating ontogenetic shifts in diet composition of Ambassis agassizii. However, Kennard (1995) described size-related changes in the diet of a similar species, Ambassis macleayi, in floodplain lagoons of the Normanby River (Cape York Peninsula, north Queensland). Results from Kennard (1995) show that smaller individuals $(<18 \mathrm{~mm}$ SL) presented a less diverse diet and relied mostly on cladocerans $(69.1 \%$ mean proportional contribution to their diet) and chironomids (18\% mean proportional contribution), whereas larger individuals ( $>18 \mathrm{~mm} \mathrm{SL}$ ) presented a more diverse diet with an increase in consumption of aquatic invertebrates (mostly chironomids, corixids, notonectids, ephemeropterans, and trichopterans) and decreased consumption of cladocerans (from 69.1\% to $44.1 \%$ ). In contrast, Arthington (1992) found that individuals of Ambassis agassizii of a size range similar to the ones examined in this study $(22-45 \mathrm{~mm}$ $\mathrm{SL}$ ) consumed exclusively aquatic insects and terrestrial material in tributary streams of the Brisbane River.

Changes associated with increasing body size, such as higher swimming speed and mouth gape size, visual acuity, and reaction distance to prey, may increase the range of prey available to a predator as it grows (Werner, 1974; Breck \& Gitter, 1983; Dunbrack \& Dill, 1983; Keast, 1985). Kennard (1995) demonstrated that small microphagic planktivore/ insectivore species were limited in prey choice by constraints in body and mouth sizes. On the whole, the fact that Ambassis agassizii fed mostly on small microcrustaceans is an indication that this species is restricted to this component of the zooplankton by mouth size and locomotory ability. Additionally, even though diets were found to differ between sampling occasions, the main dietary items were similar with only the overall proportional contribution of dietary components changing over time. It is therefore possible that resource availability had a strong influence on the diet composition of different size classes of this species. Winemiller (1989) 
recognized that food availability is a primary driver of size-related patterns of feeding among fish. According to this author, an ontogenetic switch from invertebrate (zooplankton and benthic invertebrates) to fish prey in piscivorous fish coincides with changing food availabilities associated with seasonal environmental changes. Furthermore, in a laboratory experiment O'Brien (1979) demonstrated that fish consistently selected prey that appeared to be larger, either because of their absolute size or because the prey item was closer to the fish. It is possible that the progressive increase in consumption of calanoids by A. agassizii with growth and increasing mouth size relates to this tendency to consume larger prey, as calanoids were usually larger than moinid cladocerans.

Ordination of dietary composition for sequential size classes of Leiopotherapon unicolor showed higher differentiation of smaller individuals (approx. 24-31 mm SL) from the remaining size classes examined on each sampling occasion. These smaller individuals tended to rely mostly on microcrustaceans (calanoids and daphniid cladocerans) as well as chironomid larvae and pupae. Even though these items were also important to the diet of larger fish ( $>31 \mathrm{~mm} \mathrm{SL}$ ), an increase in the consumption of aquatic invertebrates (Ecnomidae, Coenagrionidae, Corixidae, and Notonectidae) was observed in larger individuals. These results are partially in accordance with Pusey et al. (2004) who noted that smaller individuals of Leiopotherapon unicolor $(<40 \mathrm{~mm}$ SL) mostly consumed chironomid larvae whereas larger fish consumed larger prey such as Odonata and Trichoptera. Interestingly, even though the size range reported by Pusey et al. (2004) for Leiopotherapon unicolor roughly matches the size ranges examined in this study, the contribution of microcrustaceans to the mean diet of this species reported by Pusey et al. (2004) was very low, suggesting that geographic location, river type, or habitat variation must also have been an important factor. Bluhdorn \& Arthington (1994) observed that larger individuals of Leiopotherapon unicolor tended to mostly consume shrimp and occasionally fish, whereas smaller individuals ( $\leq 70 \mathrm{~mm} \mathrm{SL}$ ) consumed greater amounts of insects (larvae and ephemeropterans) and microcrustaceans (copepods and ostracods) in sub-tropical Barambah Creek, a tributary of the Burnett River, southern Queensland.
One feature of particular interest is that a spatiotemporal gradient existed in the ontogenetic shifts observed for Leiopotherapon unicolor in the present study, as different sampling occasions showed particularly different patterns in the composition of dietary items across size classes. During February 2002 at South Callandoon Lagoon West, for example, larger individuals switched from calanoid copepods as the main microcrustacean food item to ostracods and moinid cladocerans, and to a lesser extent, corixids, and the dietary contribution of calanoids at the same location was much lower during May 2002.

Nematalosa erebi also showed size-related changes in diet composition, with a clear shift from a mostly planktivorous diet (Moinidae and Calanoida) in smaller individuals $(\leq 69 \mathrm{~mm} \mathrm{TL})$ to a predominantly detritivorous diet in larger fish (>69 mm TL). Pronounced size-related patterns in the diet of Nematalosa erebi are a known feature in the dietary ecology of this species recognized by Kennard et al. (2001) and Pusey et al. (2004) among others. Bunn et al. (2003) also noted a size-related shift in stable isotope signatures of this species, reflecting a decrease in dependence on zooplankton and a greater dependence on benthic algae and terrestrial detritus as fish grew. Even though the cutoff value for the size when this species switches from a diet based on invertebrates to a more herbivorous/ detrital diet varies, in general, individuals smaller than $70 \mathrm{~mm}$ TL can be expected to have higher contributions of invertebrates to their diet. This is in accordance with results presented in this study, which shows that individuals larger than $70 \mathrm{~mm}$ TL were mostly detritivorous. Morphological changes that occur with growth of Nematalosa erebi play a major role in the dietary shifts of this species. Kennard et al. (2001) suggested that variations in diet between juveniles and adults of Nematalosa erebi probably reflect increasing mouth size as well as shifts in foraging habitat. Moreover, Atkins (1984) found that some of the morphological correlates of dietary shifts in this species included a change in mouth positioning, from dorso-terminal to terminal in fry and juveniles (related to planktivory), to ventro-terminal in adults (related to omnivory and detritivory), as well as ontogenetic changes in gut morphology, where smaller individuals have a relatively simple, straight, and short alimentary tract and only later in 
life the gizzard (used to help digest detrital/plant materials) becomes muscular and functional.

The results of this study demonstrate that zooplankton represent an important trophic resource for three species of fish selected to represent different trophic categories in the food web of floodplain waterbodies of the Macintyre River. Zooplankton are important in their own right as a major component of fish diets and are especially important to small and young individuals, even for the detritivore, Nematalosa erebi. It appears that in this and other dryland floodplain rivers of inland Australia (e.g., Cooper Creek, Lake Eyre Basin), zooplankton form an important trophic link between primary production, either autochthonous or allochthonous or both (see Bunn et al., 2003; Balcombe et al., 2005) and consumers, as suggested by Winemiller (1996) in other floodplain river systems.

Acknowledgments The authors are grateful to Griffith University for financial support during the course of this research and the Brazilian Agency for Post-Graduate Education (CAPES) for a post-graduate scholarship to Elvio Medeiros (BEX 1475/99-1). The authors also thank Dr. Glenn Wilson (formerly located at the Northern Basin Laboratory, MDFRC, Goondiwindi) for his support during field aspects of this study. Fish were collected under Queensland and New South Wales Fisheries Permit Nos. PRM00234H, PRM03315D and P01/ 0089, and Griffith University Research Ethics Protocol No. AES/02/01/aec. Completion of this paper represents a contribution to the eWater Co-operative Research Centre (Program B, Project F2).

\section{References}

Arthington, A. H., 1992. Diets and trophic guild structure of freshwater fishes in Brisbane streams. Proceedings of the Royal Society of Queensland 102: 31-47.

Arthington, A. H., S. R. Balcombe, G. A. Wilson, M. C. Thoms \& J. C. Marshall, 2005. Spatial and temporal variation in fish-assemblage structure in isolated waterholes during the 2001 dry season of an arid-zone floodplain river, Cooper Creek, Australia. Marine and Freshwater Research 56: 25-35.

Atkins, B., 1984. Feeding ecology of Nematolosa erebi in the lower River Murray. Honors Thesis, Department of Zoology. University of Adelaide, Adelaide: $82 \mathrm{pp}$.

Balcombe, S. R., S. E. Bunn, P. M. Davies \& F. J. McKenzieSmith, 2005. Variability of fish diets between dry and flood periods in an arid zone floodplain river. Journal of Fish Biology 67: 1552-1567.

Biondini, M. E., C. D. Bonham \& E. F. Redente, 1985. Secondary successional patterns in a sagebrush (Artemisia tridentata) community as they relate to soil disturbance and soil biological activity. Vegetatio 60: 25-36.

Bluhdorn, D. R. \& A. H. Arthington, 1994. The effects of flow regulation in the Barker-Barambah catchment. Griffith University, Centre for Catchment and In-Stream Research, Brisbane, Australia: 421 pp.

Breck, J. E. \& M. J. Gitter, 1983. Effect of fish size on the reactive distance of bluegill (Lepomis macrochirus) sunfish. Canadian Journal of Fisheries and Aquatic Sciences 40: $162-167$.

Bunn, S. E., P. M. Davies \& M. Winning, 2003. Sources of organic carbon supporting the food web of an arid zone floodplain river. Freshwater Biology 48: 619-635.

Dunbrack, R. L. \& L. M. Dill, 1983. A model of size dependent surface feeding in a stream dwelling salmonid. Environmental Biology of Fishes 8: 203-216.

Gerking, S. D., 1994. Feeding Ecology of Fish. Academic Press, San Diego, 416 pp.

Hyslop, E. J., 1980. Stomach contents analysis-a review of methods and their application. Journal of Fish Biology 17: 411-429.

Jones, R. I., J. Grey, D. Sleep \& L. Arvola, 1999. Stable isotope analysis of zooplankton carbon nutrition in humic lakes. OIKOS 86: 97-104.

Keast, A., 1985. The piscivore feeding guild of fishes in small freshwater ecosystems. Environmental Biology of Fishes 12: 119-129.

Kennard, M. J., 1995. Factors influencing freshwater fish assemblage in floodplain lagoons of the Normanby River, Cape York Peninsula: a large tropical Australian River. M.Sc. Thesis, Division of Environmental Science. Griffith University, Brisbane, Australia: 225 pp.

Kennard, M. J., B. J. Pusey \& A. H. Arthington, 2001. Trophic ecology of freshwater fishes in Australia. Griffith University, Centre for Catchment and In-Stream Research, Brisbane, Australia: $42 \mathrm{pp}$.

Kingsford, R. T., A. L. Curtin \& J. Porter, 1999. Water flows in Cooper Creek in arid Australia determine "boom" and "bust" periods for waterbirds. Biological Conservation 88: 231-248.

McCune, B. \& J. B. Grace, 2002. Analysis of Ecological Communities. MjM Software Design, Gleneden Beach, Oregon, U.S.A., 300 pp.

McCune, B. \& M. J. Mefford, 1999. PC-ORD. Multivariate Analysis of Ecological Data. MjM Software Design, Gleneden Beach, Oregon, U.S.A.

Medeiros, E. S. F., 2005. Trophic ecology and energy sources for fish on the floodplain of a regulated dryland river: Macintyre River, Australia. PhD Thesis, School of Australian Environmental Studies, Faculty of Environmental Sciences. Griffith University, Brisbane, Australia: xvi, $247 \mathrm{pp}$.

Medeiros E. S. F. \& A. H. Arthington, 2008. Diel variation in food intake and diet composition of three native fish species in floodplain lagoons of the Macintyre River, Australia. Journal of Fish Biology 73. doi:10.1111/j.10958649.2008.01959.x

Morton, S. R., J. Short \& R. D. Barker, 1995. Refugia for biological diversity in arid and semi-arid Australia. Biodiversity Series, Paper no. 4. Report to the Biodiversity 
Unit of the Department of Environment, Sport and Territories, Canberra, Australia: $171 \mathrm{pp}$.

O'Brien, W. J., 1979. The predator-prey interaction of planktivorous fish and zooplankton. American Scientist 67: 572-581.

Pusey, B. J., A. H. Arthington \& M. G. Read, 2000. The dryseason diet of freshwater fishes in monsoonal tropical rivers of Cape York Peninsula, Australia. Ecology of Freshwater Fish 9: 177-190.

Pusey, B. J., M. J. Kennard \& A. H. Arthington, 2004. Freshwater Fishes of North-eastern Australia. CSIRO Publishing, Melbourne, Australia, 682 pp.

Pusey, B. J., M. G. Read \& A. H. Arthington, 1995. The feeding ecology of freshwater fishes in two rivers of the Australian wet tropics. Environmental Biology of Fishes 43: 85-103.

Rodriguez, M. A. \& W. M. Lewis Jr., 1997. Structure of fish assemblages along environmental gradients in floodplain lakes of the Orinoco River. Ecological Monographs 67: 109-128.

Saint-Paul, U., J. Zuanon, M. A. Villacorta Correa, M. Garcia, N. N. Fabre, U. Berger \& W. J. Junk, 2000. Fish communities in central Amazonia white- and blackwater floodplains. Environmental Biology of Fishes 57: 235-250.

Schafer, L. N., M. E. Platell, F. J. Valesini \& I. C. Potter, 2002. Comparisons between the influence of habitat type, season and body size on dietary compositions of fish species in nearshore marine waters. Journal of Experimental Marine Biology and Ecology 278: 67-92.

Welcomme, R. L., 1985. River Fisheries. FAO Fish. Tech. Pap. No. 262, Rome, 330 pp.

Welcomme, R. L., C. Bene, C. A. Brown, A. H. Arthington, P. Dugan, J. M. King \& V. Sugunan, 2006. Predicting the water requirements of river fisheries. In Verhoeven, J. T. A., B. Beltman, R. Bobbink \& D. F. Whigham (eds.), Wetlands and Natural Resource Management. SpringerVerlag, Berlin, Heidelberg: 123-154.

Werner, E. E., 1974. The fish size, prey size, handling time relation in several sunfishes and some implications. Journal of the Fisheries Research Board of Canada 31: 1531-1536.

Werner, E. E. \& J. F. Gilliam, 1984. The ontogenetic niche and species interactions in size-structured populations. Annual Review of Ecology and Systematics 15: 393-425.

Winemiller, K. O., 1989. Ontogenetic diet shifts and resource partitioning among piscivorous fishes in the Venezuelan ilanos. Environmental Biology of Fishes 26: 177-199.

Winemiller, K. O., 1996. Factors driving temporal and spatial variation in aquatic floodplain food webs. In Polis, G. A. \& K. O. Winemiller (eds), Food Webs: Integration of Patterns and Dynamics, Vol. 472. Chapman and Hall, New York: 298-312. 